\title{
Mercury Content in Anguillicola crassus (Nematoda) and its Host Anguilla anguilla
}

\author{
M. PALÍKOVÁ ${ }^{1}$, V. BARUŠ $\check{S}^{2}$ \\ ${ }^{1}$ Department of Biology and Wildlife Diseases, \\ University of Veterinary and Pharmaceutical Sciences Brno, Czech Republic \\ ${ }^{2}$ Institute of Vertebrate Biology, Academy of Sciences of the Czech Republic, Brno, Czech Republic
}

Received January 9, 2003

Accepted May 26, 2003

\begin{abstract}
Palíková M., V. Baruš: Mercury Content in Anguillicola crassus (Nematoda) and its Host Anguilla anguilla. Acta Vet. Brno 2003, 72: 289-294.

Mercury content in parasite-host system (Anguillicola crassus and Anguilla anguilla) was studied in the Koryčany Reservoir (Czech Republic). The swimbladder nematode contained the lowest mercury levels $\left(0.050-0.183 \mathrm{mg} \mathrm{kg}^{-1}\right.$ wet weight $),(p<0.05)$, compared to muscles $(0.162$ $-0.827)$ and the liver $(0.175-1.430)$ of the fish definitive host. The mercury concentrations in the definitive host were higher in the liver, but not significantly different from muscle concentrations. Regression analysis indicated a positive ratio between mercury concentrations in the liver and the total body length of the fish. In eels from the reservoir under study the mercury content in fish muscles exceeded the hygienic limit in one fish specimen only.
\end{abstract}

Muscle, liver, parasite-host system

There is a developing body of literature analysing different amounts of heavy metals in fish and their organs and tissues (survey in Jezierska and Witesca 2001). The same tendency is manifested in comparative quantitative studies of various fish-parasite host systems (survey in Sures et al. 1999; Tenora et al. 2000; Turčeková et al. 2002). The parasite-host system of the nematode Anguillicola crassus Kuwahara, Niimi et Itagaki, 1974 and its definitive host the European eel, Anguilla anguilla L. was studied relatively frequently. Sures et al. (1994) analysed the lead content in this nematode and its host from nature only, while Zimmermann et al. (1999) did it experimentally. More heavy metal burdens (lead, cadmium, chromium and nickel) in these parasite-host systems were reported by Tenora et al. (1999). The content of selected microelements in males and females of A. crassus were studied by Baruš et al. (1999). Data on concentrations of mercury in this parasite-host system were still lacking.

In this study, therefore, we deal with the first assessment of mercury concentrations in eels and its specific parasite $A$. crassus.

\section{Materials and Methods}

The eels used in this study were caught on March 13, 2001 in the Koryčany reservoir in South Moravia (Czech Republic) by electrofishing. The Koryčany reservoir has 35.15 hectares and 20 metres in maximum depth. The description of the locality and occurrence of A. crassus was published in Palíková and Navrátil (2001) or in Navrátil et al. (1999). All fish specimens were placed in aerated aquaria filled with water from the collection site, and immediately transferred to the laboratory. In the laboratory, specimens were killed after three days and examined for metazoan parasites using standard procedures. The examination was aimed at the infection by the swimbladder nematode A. crassus, in particular. Total length ( $\mathrm{Tl}$ in $\mathrm{mm}$ ), weight ( $\mathrm{w}$ in $\mathrm{g}$ ) and infection intensity by $A$. crassus were measured in individual fish specimens (Table 1). Samples of muscles, liver of all eels $(\mathrm{n}=10)$ and collective samples of nematodes from infected eels $(n=7)$ were stored at a temperature of $-18{ }^{\circ} \mathrm{C}$. Samples were digested using $\mathrm{HNO}_{3}$ for the determination of mercury in closed system. Mercury was determined using ColdVapour Atomic Absorption Spectrometry (CV-AAS). The reproducibility precision as a relative standard deviation, limit of detection and limit of determination are in Table 2. Parallel duplicate analysis of each sample 
Table 1

Total length (Tl), weight (w) and intensity of infection by A. crassus in eels (A. anguilla) analysed for $\mathrm{Hg}$ concentration; $\mathrm{np}=$ no parasites in the swim bladder

\begin{tabular}{|c|c|c|c|c|c|c|}
\hline \multirow{3}{*}{ Eel No. } & \multirow{3}{*}{$\mathrm{Tl}(\mathrm{mm})$} & \multirow{3}{*}{$\mathrm{W}(\mathrm{g})$} & \multicolumn{4}{|c|}{ Infection intensity } \\
\hline & & & \multirow{2}{*}{ Total } & \multicolumn{3}{|c|}{ Length-group of parasites (mm) } \\
\hline & & & & $<20 \mathrm{~mm}$ & d $20 \mathrm{~mm}$ & $>20 \mathrm{~mm}$ \\
\hline 1 & 565 & 250 & $\mathrm{np}$ & \multicolumn{3}{|c|}{$\mathrm{np}$} \\
\hline 2 & 660 & 420 & $\mathrm{np}$ & \multicolumn{3}{|c|}{$\mathrm{np}$} \\
\hline 3 & 610 & 340 & 6 & 4 & 2 & 0 \\
\hline 4 & 585 & 290 & 2 & 2 & 0 & 0 \\
\hline 5 & 610 & 380 & 19 & 9 & 4 & 6 \\
\hline 6 & 630 & 390 & 4 & 1 & 1 & 2 \\
\hline 7 & 700 & 350 & 16 & 13 & 3 & 0 \\
\hline 8 & 620 & 400 & 14 & 13 & 1 & 0 \\
\hline 9 & 620 & 320 & 3 & 2 & 1 & 0 \\
\hline 10 & 560 & 290 & $\mathrm{np}$ & \multicolumn{3}{|c|}{$\mathrm{np}$} \\
\hline Mean & 616 & 343 & 9.14 & 6.3 & 1.7 & 1.1 \\
\hline SD & 42.2 & 55.4 & 7.0 & 5.3 & 1.4 & 2.3 \\
\hline
\end{tabular}

Table 2

Metrological parameters determination of $\mathrm{Hg}$ in host muscle, liver, and A. crassus by AAS

\begin{tabular}{|lc|}
\hline Limit of detection $\left(\mathrm{mg} \mathrm{kg}^{-1}\right)$ & 0.0002 \\
Limit of determination $\left(\mathrm{mg} \mathrm{kg}^{-1}\right)$ & 0.001 \\
Relative standard deviation $(\%)$ & 5 \\
\hline
\end{tabular}

was made. Minimum two blank samples in each round (eight to nine samples) were used. Each second round contained the sample of reference material. Each third round contained the matrix spike sample (Š ucman et al. 2001).

The results were statistically analysed by the Student's t-test and $c^{2}$-test using the STATplus software (Matoušková et al. 1992).

\section{Results}

The mercury concentrations in eel tissue samples and swimbladder nematode samples are summarized in Table 3.

It is evident that the $A$. crassus biomass contained the lowest mercury level compared to both eel tissues. It is well expressed by the ratio $\mathrm{R}=$ concentration $\mathrm{Hg}$ (parasite)/concentration $\mathrm{Hg}$ (host tissues), according to Sure s et al. (1999), which were in all cases below 1. Values of the ratio $\mathrm{R}$ (parasite/muscle) varied from 0.18 to 0.78 (mean 0.39 ); while the ratio $\mathrm{R}$ (parasite/liver) varied from 0.09 to 0.77 (mean 0.33). Differences of concentrations of the mercury in the parasite biomass and host tissues were significant $(p<0.05)$. Comparing the eel tissues (muscle vs. liver), the mean value of the $\mathrm{Hg}$ concentration was higher in the liver, but in individual samples it was six times higher in the liver and four times in the muscle. The difference of $\mathrm{Hg}$ concentrations in tissues of eels (muscle and liver) was not significant.

Linear regression was used to evaluate relations between concentrations of mercury and total length of fish specimens (Tl).This resulted in a lower level of significance only in the ratio of $\mathrm{Hg}$ (liver) versus $\mathrm{Tl}$ (fish) ), $\mathrm{R}^{2}=0.501$; whereas for concentrations of $\mathrm{Hg}$ in the muscle and the parasite vs. Tl (fish) the values of the regression coefficient were not significant (Fig 1). 
Table 3

Mean mercury concentrations (mg kg $\mathrm{kg}^{-1}$ wet weight) in tissues of $A$. anguilla and in the parasite A. crassus $; \mathrm{np}=$ no parasite in swim bladder (mean value $\pm \mathrm{SD}$ of repeating measurement)

\begin{tabular}{|c|c|c|c|}
\hline \multirow{2}{*}{ Eel no. } & \multicolumn{3}{|c|}{ Hg concentrations } \\
\cline { 2 - 4 } & Muscle & Liver & A. crassus \\
\hline 1 & $0.190 \pm 0.039$ & $0.246 \pm 0.049$ & $\mathrm{np}$ \\
\hline 2 & $0.299 \pm 0.057$ & $0.317 \pm 0.060$ & $\mathrm{np}$ \\
\hline 3 & $0.340 \pm 0.064$ & $0.309 \pm 0.059$ & $0.062 \pm 0.015$ \\
\hline 4 & $0.173 \pm 0.036$ & $0.175 \pm 0.036$ & $0.135 \pm 0.021$ \\
\hline 5 & $0.162 \pm 0.034$ & $0.225 \pm 0.045$ & $0.050 \pm 0.013$ \\
\hline 6 & $0.827 \pm 0.140$ & $1.170 \pm 0.180$ & $0.183 \pm 0.038$ \\
\hline 7 & $0.205 \pm 0.042$ & $1.430 \pm 0.220$ & $0.130 \pm 0.028$ \\
\hline 8 & $0.244 \pm 0.048$ & $0.257 \pm 0.050$ & $0.142 \pm 0.030$ \\
\hline 9 & $0.286 \pm 0.055$ & $0.175 \pm 0.036$ & $0.056 \pm 0.014$ \\
\hline 10 & $0.263 \pm 0.051$ & $0.139 \pm 0.030$ & $\mathrm{np}$ \\
\hline Mean & $0.299 \pm 0.057$ & $0.444 \pm 0.077$ & $0.108 \pm 0.023$ \\
\hline SD & 0.195 & 0.489 & 0.052 \\
\hline
\end{tabular}

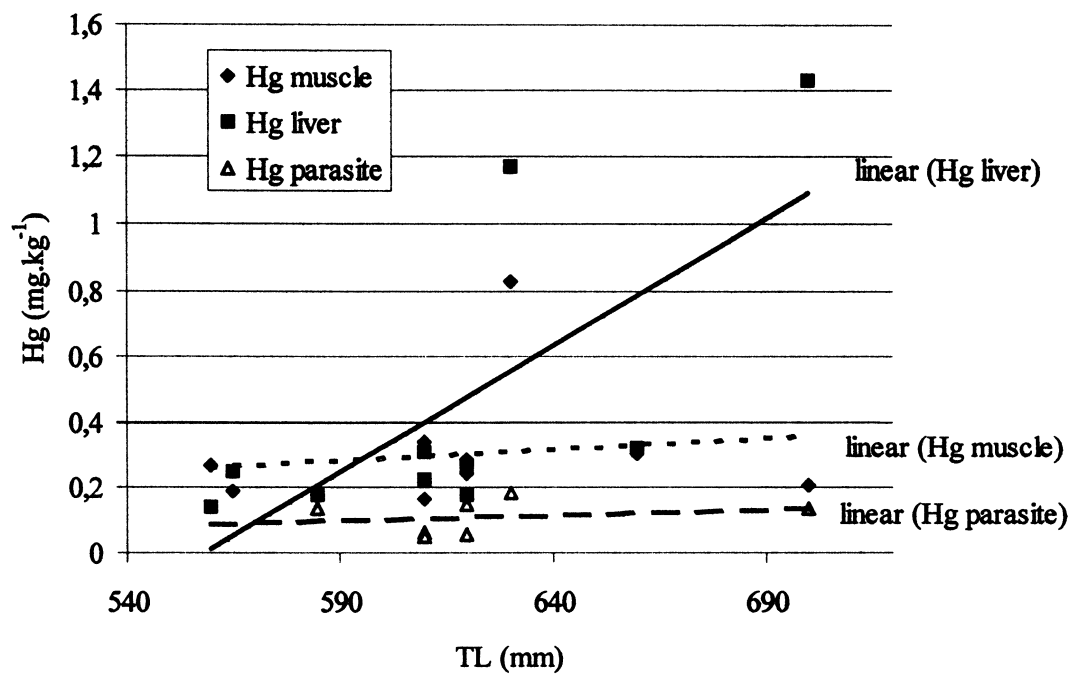

Fig 1. Concentrations of $\mathrm{Hg}$ in the host A. anguilla (muscle, liver) and in the parasite A. crassus

\section{Discussion}

From the data presented here, one may conclude that the swimbladder nematode A. crassus accumulates less mercury than the tissues of its final host eel. Thus, it seems possible that this specialised hematophagous parasite is able to excrete the mercury in detoxication processes. The same trends and results were published by Sures et al. (1994) in relation to lead concentrations in A. crassus (mean $0.02 \pm 0.01$; range $0.01-0.03$ in $\mu \mathrm{g} \mathrm{g}$ ${ }^{1}$ wet matter), and in liver of naturally infected $(n=8)$ eels $(0.18 \pm 0.05$; range $0.12-0.28)$ from the river Weser (Germany). The size (age groups) of adult worms did not differ in this 
aspect. The results in this parasite-host system were confirmed experimentally by Zimmermann et al. (1999).

The four heavy metal concentrations (lead, cadmium, chromium and nickel) in this parasite-host system were analysed by Tenora et al. (1999). Regarding the methodical differences (concentrations of heavy metals were expressed in $\mu \mathrm{g} \mathrm{\textrm {g } ^ { - 1 }}$ of $100 \%$ of dry matter), the authors found higher concentrations in males and females of the A. crassus than in the muscle samples of eels for lead (mean values $1.41 \pm 0.02$ in males; $0.41 \pm 0.03$ in females; $0.18 \pm 0.03$ in muscle), for cadmium $(0.74 \pm 0.01$ in males; $0.20 \pm 0.01$ in females; $0.09 \pm 0.02$ in muscle), for chromium (1.05 \pm 0.03 in males; $0.35 \pm 0.03$ in females; $0.08 \pm$ 0.02 in muscle) and for nickel (1.21 \pm 0.03 in males; $0.39 \pm 0.02$ in females; $0.08 \pm 0.02$ in muscle). It is remarkable that in the biomass of $A$. crassus males (which in the adult stage are always of smaller dimensions and consume evidently less host blood during their life than females do) there were found higher heavy metal concentrations. Sexually determined differences in concentrations of selected microelements (iron, zinc, manganese, copper and cobalt) were also found in A. crassus biomass by B aruš et al. (1999). The survey of results, however, indicates unambiguously that the accumulation and concentration values of heavy metals in A. crassus are in comparison to other fish parasite species (acanthocephalans and tapeworms, in particular) considerably lower. Values of the ratio (R) vary according to Tenora et al. (1999) for males of A. crassus vs. eel muscle in the range of $7.8-15.1$, for females of $A$. crassus vs. muscle between 2.3 - 4.9, only. For the mercury, according to our results the efficacy of accumulation and the values of concentrations in A. crassus are comparably low as for the lead (Sure s et al. 1994). According to Tenora et al. (2000) the only species of the nematode, Philometra ovata Zeder, 1803, infecting the body cavity of cyprinid fishes is known to accumulate more heavy metals than the muscle of the host, i.e., the bream (Abramis brama L.). The respective values for lead, chromium and cadmium in the parasite were 106, 43.5 and 119 times higher than in fish muscle samples.

Low efficacy of mercury accumulation (and also of other heavy metals) that we found in $A$. crassus enables to exclude in this parasite-host system the influence of the parasite on decreasing the heavy metal concentrations in body tissues of infected fish specimens. The influence of infection by the tapeworm Proteocephalus percae Müller, 1780 in the perch (Percafluviatilis L.) on decreasing of concentrations of cadmium, copper, zinc and arsenic was described by Turčeková and Hanzelová (1999) and Turčeková et al. (2002); for lead, nickel and chromium concentrations in the barbel (Barbus barbus L.) infected by tapeworm Bathybothrium rectangulum Bloch, 1782 it was also mentioned by B aruš et al. (2001).

In this way, the eel may serve as a fish species for effective bio-indication in dependence of the region (e.g. Pieters and Geuke 1994).

The data on mercury concentrations in eels from various localities in the Czech Republic were presented by Studnicka et al. (1974); Hejtmánek et al. (1975); Svobodová and Hejtmánek (1976); Peňáz et al. (1980) and S vobodová et al. (1988, 1993). In eels from rivers the mercury concentrations ranged from 0.045 to $0.661 \mathrm{mg} \mathrm{kg}^{-1}$ wet matter in muscle samples, and from 0.341 to 1.365 in liver tissue. In eels from the water supply reservoirs (Želivka reservoir, in particular) mercury concentrations ranged from 0.506 to 2.40 in muscle, and from 0.286 to 5.76 in liver. Mas on (1987) recorded the mercury concentration in the range $0.09-0.66 \mathrm{mg} \mathrm{kg}^{-1}$ in eel flesh from East Anglia Sites, Richards and Dulley (1983) in the range of $0.07-0.68$ in eels from tidal Thames. According to Barak and Mason (1990) in the liver and muscle of eels the concentrations of the mercury varied between 0.02 - 0.38 and 0.09 - 0.83, respectively, in fish from the Rivers Brett and Chelmer in eastern England. Mercury levels in eel flesh and liver tissue in the study site were similar to those reported from this fish species in the Czech and the British waters. According to Barak and Mason (1990), Svobodová et al. (1999) and Goldstein et al. (1996) in 
highly polluted sites the level of mercury in liver tissues and gonads increased significantly compared to muscle tissue, particularly in predator fish species. Concentrations of mercury found at the site under study indicated rather lower mercury load. This was the case because even with higher mean mercury concentration in the liver as compared to the muscle the difference was not significant. The mercury content in the liver regressed on the $\mathrm{Tl}$ (age) of eels only, but not significantly. This result was probably influenced by temporal variability, small number of fish in collection, and also habitat preference during the season.

According to Czech assessment values, the content of mercury in muscle tissues higher than $0.6 \mathrm{mg} \mathrm{kg}^{-1}$ in predatory fish species is considered as significantly exceeding hygienic limits. Predators (eels in this study) from the Koryčany reservoir exceeded the limit only in one fish specimen examined, while in all others the concentrations are evidently lower.

\section{Obsah rtuti u krevnatky úhoří (Anguillicola crassus, Nematoda) a jejího definitivního hostitele, úhoře říčního (Anguilla anguilla)}

$\mathrm{V}$ práci je uveden výskyt rtuti $\mathrm{v}$ parazito-hostitelském systému krevnatka úhoří (Anguillicola crassus) a úhoř říční (Anguilla anguilla) ve vodárenské nádrži Koryčany (Česká republika). Parazit plynového měchýře vykazuje nejnižší hladinu rtuti $(0.050$ $\left.0.183 \mathrm{mg} \mathrm{kg}^{-1}\right),(p<0.05)$, oproti jejímu obsahu ve svalovině $(0.162-0.827)$ a v játrech (0.175 - 1.430) definitivního hostitele. Obsah rtuti v definitivním hostiteli byl vyšší v játrech, ale ne statisticky průkazně. Regresní analýza dokumentuje pozitivní vztah koncentrace rtuti s celkovou délkou těla úhořů. $\mathrm{V}$ rámci tohoto sledování byl pouze $\mathrm{v}$ jednom případě překročen hygienický limit rtuti ve svalovině úhořu.

\section{Acknowledgement}

This paper was financially supported by the Research Intention of the Ministry of Education of the Czech Republic MŠMT No. CEZ:J16/98:162700004, by the Morava River Catchment Area Administration Company as a part of the health condition of fish monitoring in water reservoirs, and by the Grant Agency of the Czech Republic, No. 524/03/0061.

\section{References}

BARAK, NAE, MASON, CF 1990: Mercury, cadmium and lead in eels and roach: The effects of size, season and locality on metal concentrations in flesh and liver. Sci Total Environ 92: 249-256

BARUŠ, V, TENORA, F, KRÁČMAR, S, PROKEŠ, M, DVOŘÁČEK, J 1999: Microelement contents in males and females of Anguillicola crassus (Nematoda: Dracunculoidea). Helmintologia 36: 283-285

BARUŠ, V, TENORA, F, PROKEŠ, M, PEŇÁZ, M 2001: Heavy metals in parasite-host systems: tapeworm vs. fish. In Czech.In: Ochrana zdraví ryb (Health protection of fish), Vodňany, pp. 20-28

GOLDSTEIN, RM, BRIGHAM, ME, STAUFFER, JC 1996: Comparison of mercury concentrations in liver, muscle and whole bodies, and composites of fish from the Red River of the North. Can J Fish Aquat Sci 53: 244-252

HEJTMÁNEK, M, SVOBODOVÁ, Z, STUDNICKA, M 1975: Total mercury content in the musculature of fishes from dam Lakes in Bohemia. Acta Vet. Brno 44: 53-58

JEZIERSKA, B, WITESKA, M 2001: Metal toxicity to fish. Monography No 42. Wydawnictwo Academii Podlaskiej, Siedlce, 318 p.

MASON, CF 1987: A survey of mercury, load and cadmium in muscle of British freshwater fish. Chemosphere 16: $901-906$

MATOUŠKOVÁ, O, CHALUPA, J., CÍGLER, M., HRUŠKA, K. 1992: Statistic system STATplus, version 1,01. Institute of Veterinary Medicine, Brno, 1992, 168pp.

NAVRÁTIL, S, PALÍKOVÁ, M, KLEMENT, R 1999: Anguillicolosis of eels in water reservoirs of the Morava River basin. Helmintologia 36:129

PALÍKOVÁ, M, NAVRÁTIL, S 2001: Occurrence of Anguillicola crassus in the water reservoir Koryčany (Czech Republic) and its influence on the health condition and haematological indices of eels. Acta Vet. Brno 70: 443449

PEÑÁZ, M, SVOBODOVÁ, Z, HEJTMÁNEK, M, TRNKOVÁ, J, WOHLGEMUTH, E 1980: Mercury content in the basic components of the ecosystem of the Jihlava river. In Czech Bulletin VÚRH Vodňany 1: 24-30.

PIETERS, H, GEUKE, V 1994: Methyl mercury in Dutch Rhine delta. Water Qual Int 30: 213-219

RICHARDS, DG, DULLEY, MER 1983: The levels of some heavy metals and chlorinated hydrocarbons in fish from the tidal Thames. Environ Pollut (Series B) 5: 101-119 
STUDNICKA, M, HEJTMÁNEK, M, SVOBODOVÁ, Z 1974: Determination of mercury contents in muscles of fishes from the river Vltava and its tributary streams. Acta Vet Brno 42:145-151

SURES, B, SIDDAL, R, TARASCHEWSKI, H 1999: Parasites as accumulation indicators of heavy metal pollution. Parasitol Today 15: 16-21

SURES, B, TARASCHEWSKI, H, JACKWERTH, E 1994: Lead content of Paratenuisentis ambiguus (Acanthocephala), Anguillicola crassus (Nematodes) and their host Anguilla anguilla. Dis Aquat Org 19: 105107

SVOBODOVÁ Z, HEJTMÁNEK M 1976: Total mercury content in the musculature of fishes from the river Ohře and its tributaries. Acta Vet. Brno 45: 45-49

SVOBODOVÁ, Z, HEJTMÁNEK, M, PŘIKRYL, I, KOCOVÁ, A 1988: The content of total mercury in the individual components of the ecosystem of the Želivka water supply reservoir. II. Fish. In Czech Bulletin VÚRH Vodňany 4: 3-15.

SVOBODOVÁ, Z, VYKUSOVÁ, B, MÁCHOVÁ, J, BASTL, J, HRBKOVÁ, M, SVOBODNÍK, J 1993: Monitoring of foreign substances in fishes from the Elbe river in the Čelákovice locality. In Czech. Bulletin VÚRH Vodňany 29: 47-61.

SVOBODOVÁ, Z, DUŠEK, L, HEJTMÁNEK, M, VYKUSOVÁ, B, ŠMÍD, R 1999: Bioaccumulation of mercury in various fish species from Orlík and Kamýk water reservoirs in the Czech Republic. Ecotox Environ Safety 43: $231-240$

ŠUCMAN, E, VÁVROVÁ, M, ZIMA, S, KOŘÍNEK, P, PAVELKA, J, ZLÁMALOVÁ GARGOŠOVÁ, H 2001: Studies on the transfer of harmful substances from feed chicken tissues. Canad J Anal Sci Spect 46: 89-94

TENORA, F, BARUŠ, V, KRÁČMAR, S, DVOŘÁČEK, J 2000: Concentrations of some heavy metals in Ligula intestinalis plerocercoids (Cestoda) and Philometra ovata (Nematoda) compared to some theirs host (Osteichthyes). Helmintologia 37: 15-18

TENORA, F, BARUŠ, V, KRÁČMAR, S, DVOŘÁČEK, J, SRNKOVÁ, J 1999: Parallel analysis of some heavy metals concentrations in the Anguillicola crassus (Nematoda) and the European eel Anguilla anguilla (Osteichthyes). Helmintologia 36: 79-81

TURČEKOVÁ, L, HANZELOVÁ, V 1999: Concentrations of Cd, As and Pb in non-infected and infected Perca fluviatilis with Proteocephalus percae. Helmintologia 36 (Suppl.): 31

TURČEKOVÁ, L, HANZELOVÁ, V, ŠPAKULOVÂ, M 2002: Concentration of heavy metals in perch and its endoparasites in the polluted water reservoir in Eastern Slovakia. Helmintologia 39: 23-28

ZIMMERMANN, S, SURES, B, TARASCHEWSKI, H 1999: Experimental studies on lead accumulation in the eel-specific endoparasites Anguillicola crassus (Nematoda) and Paratenuisentis ambiguus (Acanthocephala) as compared with their host, Anguilla anguilla. Arch Environ Contam Toxicol 17: 190-195 